\title{
A Progeny Virus from a Cucumovirus Pseudorecombinant Evolved to Gain the Ability to Accumulate Its RNA-Silencing Suppressor Leading to Systemic Infection in Tobacco
}

\author{
Ryota Asaoka, Hanako Shimura, Makoto Arai, and Chikara Masuta \\ Laboratory of Cell Biology and Manipulation, Graduate School of Agriculture, Hokkaido University, Sapporo 060-8589, Japan \\ Submitted 7 August 2009. Accepted 19 October 2009.
}

Two isolates of Tomato aspermy virus (TAV), V-TAV and CTAV, can systemically infect Nicotiana benthamiana but only C-TAV can move systemically in N. tabacum. Any pseudorecombinants between the two strains could not move systemically in tobacco as efficiently as C-TAV. However, a pseudorecombinant consisting of RNAs 1 and 3 of V-TAV and RNA 2 of C-TAV (V1C2V3), which cannot infect tobacco systemically, generated progeny with a mutation in $\mathrm{V} 1$ and a recombination in $\mathrm{C2}\left(\mathrm{V}^{\mathrm{m}} \mathrm{C}^{\mathrm{r}} \mathrm{V3}\right)$, enabling the virus to move systemically. To avoid further mutation and recombination in the virus, we used Cucumber mosaic virus RNA3 (Y3) for subsequent experiments. Northern blot analyses showed that RNA4A, which encodes the $2 b$ protein (2b), and RNA5 abundantly accumulated in $\mathrm{V1}^{\mathrm{m}} \mathrm{C} 2^{\mathrm{r}} \mathrm{Y} 3$-infected tobacco. $\mathrm{V1}^{\mathrm{m}} \mathrm{C} 2^{\mathrm{r}} \mathrm{Y} 3$ actually caused higher accumulation of $2 \mathrm{~b}$ than did V1C2Y3 in Western blots, and overexpression of $2 b$ by the PVX vector enabled V1C2Y3 to move systemically in tobacco, suggesting that $2 \mathrm{~b}$ accumulation promotes viral systemic movement. Because RNA-silencing suppressor (RSS) activity of $2 \mathrm{~b}$ was thought to be involved in systemic movement, we compared the RSS activity of $2 \mathrm{~b}$ for the two TAV isolates; C-TAV 2b had stronger activity than did V-TAV 2b in tobacco in a transient protoplast assay. Our data also demonstrated that $2 \mathrm{~b}$ and RNA5 play an important role in the evolution of members of genus Cucumovirus by generating mutant/recombinant viruses and viral systemic movement over RNA silencing.

Cucumber mosaic virus (CMV) and Tomato aspermy virus (TAV) belong to the genus Cucumovirus. They have tripartite, plus-sense RNAs designated RNAs 1, 2, and 3 in decreasing order of molecular weight. RNAs 1 and 2 encode replicase proteins (1a and $2 \mathrm{a}$, respectively) and RNA3 encodes the movement protein (3a). The coat protein $(\mathrm{CP})$ is translated from a subgenomic RNA, RNA4, derived from RNA3. RNA4A is a subgenomic RNA generated from the $3^{\prime}$ end of RNA 2 and encodes the $2 b$ protein $(2 b)$, which has been shown to play a role in cell-to-cell and systemic movement of cucumoviruses as well as in symptom induction (Ding et al. 1995;

Corresponding author: C. Masuta; Telephone: +81 11 7062807; Fax: +81 11 7062483; E-mail: masuta@ res.agr.hokudai.ac.jp

R. Asaoka and H. Shimura contributed equally to this work.

* The $e$-Xtra logo stands for "electronic extra" and indicates that four supplementary figures are published online.
Ji and Ding 2001; Soards et al. 2002; Shi et al. 2003; Lewsey et al. 2009). The $2 \mathrm{~b}$ protein also acts as an RNA-silencing suppressor (RSS) (Brigneti et al. 1998). It has been suggested that 2b inhibits RNA silencing by binding either small RNAs (Goto et al. 2007) or AGO1 (Zhang et al. 2006), a component of the RNA-induced silencing complex (RISC).

In nature, mixed infections with two or more viruses are common; thus, genetic material may be rearranged or exchanged between viral species as well as within species. In many experiments using cucumoviruses, RNA-RNA recombination has been shown between CMV isolates (Chen et al. 2002; Lin et al. 2004; Bonnet et al. 2005), within a CMV isolate (Canto et al. 2001), and between CMV and TAV (Aaziz and Tepfer 1999; de Wispelaere et al. 2005). In addition, recombination can occur within a pseudorecombinant virus containing RNAs 1 and 2 from CMV and RNA3 from TAV (Fernández-Cuartero et al. 1994; Shi et al. 2003). Recombination between viral genomes of different RNA viruses and further mutations maintain variability in the viral genome and facilitate evolution of new viruses (Masuta et al. 1998; Suzuki et al. 2003; de Wispelaere et al. 2005; Shi et al. 2008). These events are not necessarily independent but are sometimes closely linked.

We describe here that a pseudorecombinant between two isolates of TAV (V-TAV and C-TAV) enhances both mutation and recombination simultaneously. V-TAV and C-TAV can systemically infect Nicotiana benthamiana and cause severe symptoms. When N. tabacum was inoculated, however, C-TAV caused systemic symptoms but V-TAV was localized in the inoculated leaf. A pseudorecombinant virus consisting RNAs 1 and 3 of V-TAV and RNA2 of C-TAV (V1C2V3) cannot infect tobacco systemically, but a spontaneous mutant/recombinant virus $\left(\mathrm{V} 1{ }^{\mathrm{m}} \mathrm{C} 2{ }^{\mathrm{r}} \mathrm{V} 3\right)$ generated from the $\mathrm{V} 1 \mathrm{C} 2 \mathrm{~V} 3$ progeny spread systemically in tobacco. Cucumovirus systemic movement and symptom induction are believed to be due to the activity of $2 b$ to interfere with the host RNA silencing and with the salicylicacid-dependent defense response (Ji and Ding 2001); however, it is still unclear how $2 \mathrm{~b}$ activity can control viral systemic infection. In the process of infection, overtaking such host defense responses more efficiently may contribute to generation and survival of a spontaneous mutant/recombinant virus leading to successful systemic movement.

In this study, we investigated how the RSS-related effect can control the TAV systemic movement in tobacco. In a comparative study using $\mathrm{V} 1 \mathrm{C} 2 \mathrm{~V} 3$ and its progeny virus $\left(\mathrm{V} 1^{\mathrm{m}} \mathrm{C} 2^{\mathrm{r}} \mathrm{V} 3\right)$, we sought to determine factors needed for systemic infection of cucumoviruses. In addition, we used a protoplast assay (Shimura et al. 2008) to quantitate RSS activities of TAV $2 \mathrm{bs}$ 
to relate the $2 \mathrm{~b}$ RSS ability to systemic movement of the virus. Here, we show that the level of $2 b$ accumulation plays an important role in promoting systemic movement and, perhaps, evolution of mutant/recombinant viruses. We also discuss a role of RNA5 in increasing the levels of viral RNAs, including RNA4A encoding $2 b$.

\section{RESULTS}

\section{A pseudorecombinant virus between two TAV isolates prompted both mutation and recombination, leading to viral systemic movement.}

To identify the RNA genome that controls systemic movement in tobacco, pseudorecombinants were created between the two isolates of TAV. We previously constructed infectious cDNA clones of an isolate of TAV designated V-TAV (J) (Masuta et al. 1998). Here, we prepared infectious cDNA

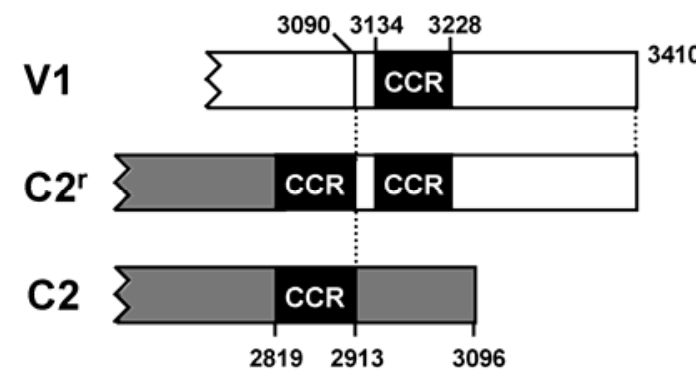

Fig. 1. Recombination between two isolates of Tomato aspermy virus (TAV), V-TAV and C-TAV. The 3'-terminal 183 nucleotides (nt) of RNA2 of C-TAV were replaced by the 3'-terminal 321 nt of RNA1 of V-TAV containing the cucumovirus conserved region (CCR) (Suzuki et al. 2003). V1 $=$ RNA 1 of V-TAV, C2 $=$ RNA2 of C-TAV. Sequencing of the cDNA clones revealed that about $90 \%$ of the RNA2 molecules were the recombinant RNA 2, designated $\mathrm{C}^{\mathrm{r}}$. clones of another TAV isolate (C-TAV) isolated from chrysanthemum in Japan. The two TAV isolates differ in their infectivity in tobacco; $\mathrm{C} 1 \mathrm{C} 2 \mathrm{C} 3$ (i.e., C-TAV RNAs 1 to 3) can systemically infect tobacco but V1V2V3 (i.e., V-TAV [J] RNAs 1 to 3 ) is localized in the inoculated leaf (Table 1). Inoculation experiments with different pseudorecombinants revealed that C2 was an important but not absolute determinant (Table 1). Although we observed symptoms at 14 days postinoculation (dpi) on the upper uninoculated leaves of plants that had been inoculated with some pseudorecombinants, the plants did not necessarily develop more systemic symptoms by 30 dpi (Table 1). Consequently, we were not able to reproduce the systemic movement of C-TAV in any pseudorecombinants prepared.

When we coinoculated $N$. benthamiana with V1 and V3 along with $\mathrm{C} 2$, the progeny $\mathrm{V} 1 \mathrm{C} 2 \mathrm{~V} 3$ virus had a recombinant RNA generated between C2 and V1 (Fig. 1). The C2 3' terminal (183 nucleotides [nt]) was replaced with the corresponding

Table 1. Systemic movement of pseudorecombinants in Nicotiana tabacum

\begin{tabular}{lccc}
\hline & & \multicolumn{2}{c}{ Systemic symptoms $^{\mathbf{a}}$} \\
\cline { 3 - 4 } Inoculum & Inoculated leaf $^{\mathbf{b}}$ & $\mathbf{1 4} \mathbf{~ d p i}$ & $\mathbf{3 0 ~ d p i}$ \\
\hline Wild type & & & \\
V1V2V3 & + & $0 / 20$ & $0 / 20$ \\
C1C2C3 & + & $17 / 20$ & $17 / 20$ \\
Pseudorecombinants & & & \\
C1V2V3 & + & $1 / 10$ & $0 / 10$ \\
V1C2V3 & + & $8 / 15$ & $5 / 15$ \\
C1C2V3 & + & $12 / 15$ & $5 / 15$ \\
C1V2Y3 & + & $8 / 15$ & $0 / 15$ \\
V1C2Y3 & + & $0 / 15$ & $0 / 15$ \\
C1C2Y3 & + & $12 / 15$ & $2 / 15$ \\
V1V2Y3 & + & $0 / 15$ & $0 / 15$ \\
\hline
\end{tabular}

${ }^{a}$ Symptoms on the second upper leaf at 14 days postinoculation (dpi) and on the top expanded leaf at $30 \mathrm{dpi}$. Tobacco plants at six-leaf-stage were inoculated.

${ }^{\mathrm{b}}$ Detected by enzyme-linked immunosorbent assay.
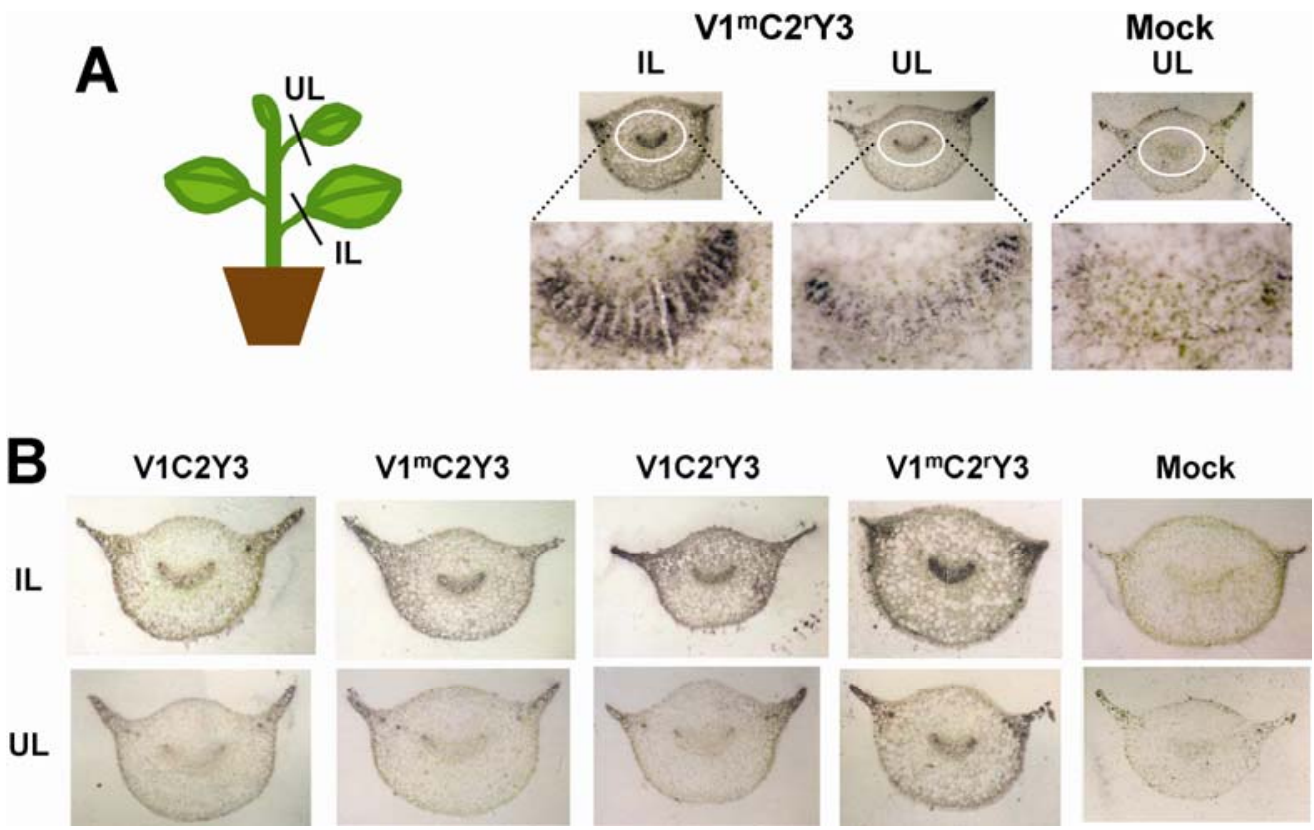

Fig. 2. Tissue printing of the leaves of Nicotiana tabacum inoculated with pseudorecombinants containing V1 mutation and C2 recombination. A, Diagram to show inoculated leaf (IL) and upper leaf (UL) harvested for tissue printing analysis. Virus was detected 14 days postinoculation in the petiole cross-section from the IL and UL using antibodies raised against the coat protein of Cucumber mosaic virus Y (CMV-Y). Black areas in photographs indicate the presence of the virus. When tobacco was inoculated with $\mathrm{V} 1{ }^{\mathrm{m}} \mathrm{C} 2^{\mathrm{r}} \mathrm{Y} 3$, virus accumulated in the vascular bundles of IL and UL (enlarged images of IL and UL). No black areas developed in prints from tissues in the mock treatment. B, Comparison of tissue prints to show viral systemic movements between V1C2Y3 and mutant/recombinant pseudorecombinants. Only $\mathrm{V}^{\mathrm{m}} \mathrm{C} 2^{\mathrm{r}} \mathrm{Y} 3$ successfully spread in both IL and UL. Other pseudorecombinants accumulated in IL but they failed to move systemically. V1 = RNA1 of Tomato aspermy virus $(\mathrm{TAV}) \mathrm{V}$ strain, $\mathrm{V} 1^{\mathrm{m}}=$ containing a mutation at position $1,767, \mathrm{C} 2=\mathrm{RNA} 2$ of $\mathrm{C}$-TAV, $\mathrm{C} 2^{\mathrm{r}}=$ a recombinant $\mathrm{C} 2$ containing the $3^{\prime}$ end of $\mathrm{V} 1, \mathrm{Y} 3=\mathrm{RNA} 3$ of $\mathrm{CMV}-\mathrm{Y}$. 
region of V1 (321 nt) and contained a duplication of the 95-ntlong Cucumovirus-conserved region (CCR) (Suzuki et al. 2003). In addition, $\mathrm{V} 1$ contained a mutation at nucleotide position 1,767, resulting in one amino acid change (A to $\mathrm{V}$ ) in the helicase domain of the 1a protein. The mutant RNA1 and the recombinant RNA2 were designated $\mathrm{V}^{\mathrm{m}}$ and $\mathrm{C} 2^{\mathrm{r}}$, respectively. $\mathrm{V} 1$ was completely replaced by $\mathrm{V} 1^{\mathrm{m}}$ in the RNA1 quasispecies. $\mathrm{C} 2{ }^{\mathrm{r}}$ outcompeted the authentic $\mathrm{C} 2$ and evolved to be the dominant species; approximately $90 \%$ of viral RNA2 in sequenced cDNA clones was $\mathrm{C}^{\mathrm{r}}$. The most outstanding phenotypic change was that $\mathrm{V} 1^{\mathrm{m}} \mathrm{C} 2^{\mathrm{r}} \mathrm{V} 3$ gained the ability to infect $N$. tabacum systemically although the parental virus V1C2V3 was initially inoculated onto $N$. benthamiana and, thus, no selection pressure was imposed for the viral systemic infection in tobacco.

Both V1 mutation and $\mathrm{C} 2$ recombination in the spontaneous virus are necessary for viral systemic movement.

We then reconstructed infectious transcripts of $\mathrm{V} 1^{\mathrm{m}}$ and $\mathrm{C} 2^{\mathrm{r}}$. For the infectious transcript for RNA3, we used RNA3 of CMV-Y (Y3), which can systemically infect both $N$. benthamiana and tobacco. Because the presence of V3 appeared to induce numerous mutations on the RNA genomes for unknown reasons, we could not trace the sequences responsible for the phenotypic changes in the progeny viruses. When $N$. benthamiana was inoculated with $\mathrm{Y} 3$ along with $\mathrm{V} 1^{\mathrm{m}}$ and $\mathrm{C} 2^{\mathrm{r}}$, the pseudorecombinants $\mathrm{V} 1{ }^{\mathrm{m}} \mathrm{C} 2^{\mathrm{r}} \mathrm{Y} 3$ could infect tobacco systemically, and we did not observe any mutation and recombination in the virus (Fig. 2; Table 2).

To examine which RNA $\left(\mathrm{V} 1^{\mathrm{m}}, \mathrm{C} 2^{\mathrm{r}}\right.$, or both) is required for systemic infection, we inoculated tobacco plants with several pseudorecombinants containing the mutation or recombination. We observed systemic symptoms at 14 and 30 dpi on the upper leaves of plants that had been inoculated with either $\mathrm{V} 1{ }^{\mathrm{m}} \mathrm{C} 2{ }^{\mathrm{r}} \mathrm{Y} 3$ or $\mathrm{V} 1{ }^{\mathrm{m}} \mathrm{C} 2{ }^{\mathrm{r}} \mathrm{V} 3$, but neither $\mathrm{V} 1{ }^{\mathrm{m}} \mathrm{C} 2 \mathrm{Y} 3$ nor $\mathrm{V} 1 \mathrm{C} 2^{\mathrm{r}} \mathrm{Y} 3$ caused systemic symptoms (Table 2). Using tissue printing, we further examined the distribution of $\mathrm{V} 1{ }^{\mathrm{m}} \mathrm{C} 2^{\mathrm{r}} \mathrm{Y} 3$ within the systemically infected plants. All pseudorecombinants accumulated in the vascular tissue of the petiole of the inoculated leaves but only $\mathrm{V} 1^{\mathrm{m}} \mathrm{C} 2^{\mathrm{r}} \mathrm{Y} 3$ containing both $\mathrm{V} 1$ mutation and $\mathrm{C} 2$ recombination was detected in the vascular tissue of the petiole of the upper leaves (Fig. 2). These results suggest that both $\mathrm{V} 1^{\mathrm{m}}$ and $\mathrm{C} 2^{\mathrm{r}}$ were important for viral long-distance movement within the phloem after leaving the inoculated leaf.

\section{Large amounts of RNA4A and RNA5 were detected} in the inoculated tissues infected with $\mathrm{V1}^{\mathrm{m}} \mathrm{C} 2^{\mathrm{r}} \mathrm{Y} 3$ and in protoplasts and the viral particle.

In a comparative study between parental TAV and the pseudorecombinants containing the mutation/recombination, we investigated factors involved in the successful systemic movement of $\mathrm{V} 1{ }^{\mathrm{m}} \mathrm{C} 2{ }^{\mathrm{r}} \mathrm{Y} 3$. In Northern blots, $\mathrm{C} 1 \mathrm{C} 2 \mathrm{C} 3$ caused the

Table 2. Effects of the recombination and mutation on the viral systemic symptoms

\begin{tabular}{lccc}
\hline & & \multicolumn{2}{c}{ Systemic symptoms $\mathbf{s}^{\mathbf{a}}$} \\
\cline { 3 - 4 } Inoculum & Inoculated leaf $^{\mathbf{b}}$ & $\mathbf{1 4} \mathbf{d p i}$ & $\mathbf{3 0 ~ d p i}$ \\
\hline $\mathrm{V} 1 \mathrm{~V} 2 \mathrm{~V} 3$ & + & $0 / 10$ & $0 / 10$ \\
$\mathrm{~V} 1^{\mathrm{m}} \mathrm{C} 2^{\mathrm{r}} \mathrm{V} 3$ & + & $7 / 10$ & $7 / 10$ \\
$\mathrm{~V} 1^{\mathrm{m}} \mathrm{C} 2^{\mathrm{r}} \mathrm{Y} 3$ & + & $10 / 10$ & $10 / 10$ \\
$\mathrm{~V}^{\mathrm{m}} \mathrm{C} 2 \mathrm{Y} 3$ & + & $0 / 10$ & $0 / 10$ \\
$\mathrm{~V} 1 \mathrm{C} 2^{\mathrm{r}} \mathrm{Y} 3$ & + & $0 / 10$ & $0 / 10$ \\
$\mathrm{C} 1 \mathrm{C} 2^{\mathrm{r}} \mathrm{Y} 3$ & + & $3 / 10$ & $0 / 10$ \\
\hline
\end{tabular}

${ }^{\mathrm{a}}$ Symptoms on the second upper leaf 14 days postinoculation (dpi) and on the top expanded leaf 30 days dpi.

${ }^{\mathrm{b}}$ Detected by enzyme-linked immunosorbent assay. accumulation of more genomic RNAs, including RNA4A and RNA5, than did V1V2V3 in the inoculated tobacco leaves (Fig. 3A). RNA5 is known to be associated with TAV and subgroup II strains of CMV and has been suggested to be a mixed population derived from the 3 '-terminal untranslated region (UTR) of RNA3 and RNAs 1 or 2 as found in CMV (Blanchard et al. 1996; Shi et al. 1997). In comparison among pseudorecombinants, $\mathrm{V} 1{ }^{\mathrm{m}} \mathrm{C} 2^{\mathrm{r}} \mathrm{Y} 3$ caused the accumulation of much more RNA3, RNA4A, and RNA5 than V1C2Y3. On the other hand, $\mathrm{V} 1{ }^{\mathrm{m}} \mathrm{C} 2 \mathrm{Y} 3$ and $\mathrm{V} 1 \mathrm{C} 2^{\mathrm{r}} \mathrm{Y} 3$ did not cause the accumulation of any detectable RNA4A, perhaps due to a low level of RNA2, although a strong band for RNA4 and a faint band for RNA5 were present in $\mathrm{V} 1 \mathrm{C} 2^{\mathrm{r}} \mathrm{Y} 3$. The accumulation of RNAs 1 and 2 significantly decreased in all pseudorecombinants that contained Y3 as RNA3 (Fig. 3A). When the intensity of the band for RNA4A of $\mathrm{V} 1 \mathrm{~V} 2 \mathrm{~V} 3$ and $\mathrm{V} 1^{\mathrm{m}} \mathrm{C} 2{ }^{\mathrm{r}} \mathrm{Y} 3$ detected by Northern blots was compared, the RNA4A band of $\mathrm{V} 1^{\mathrm{m}} \mathrm{C} 2^{\mathrm{r}} \mathrm{Y} 3$ was approximately 2.5 -fold higher than that of V1C2Y3 (Fig. 3B). These results were also confirmed by real-time reversetranscription polymerase chain reaction (PCR) analysis using the same RNA samples for Northern blots (Supplementary Fig. S1).
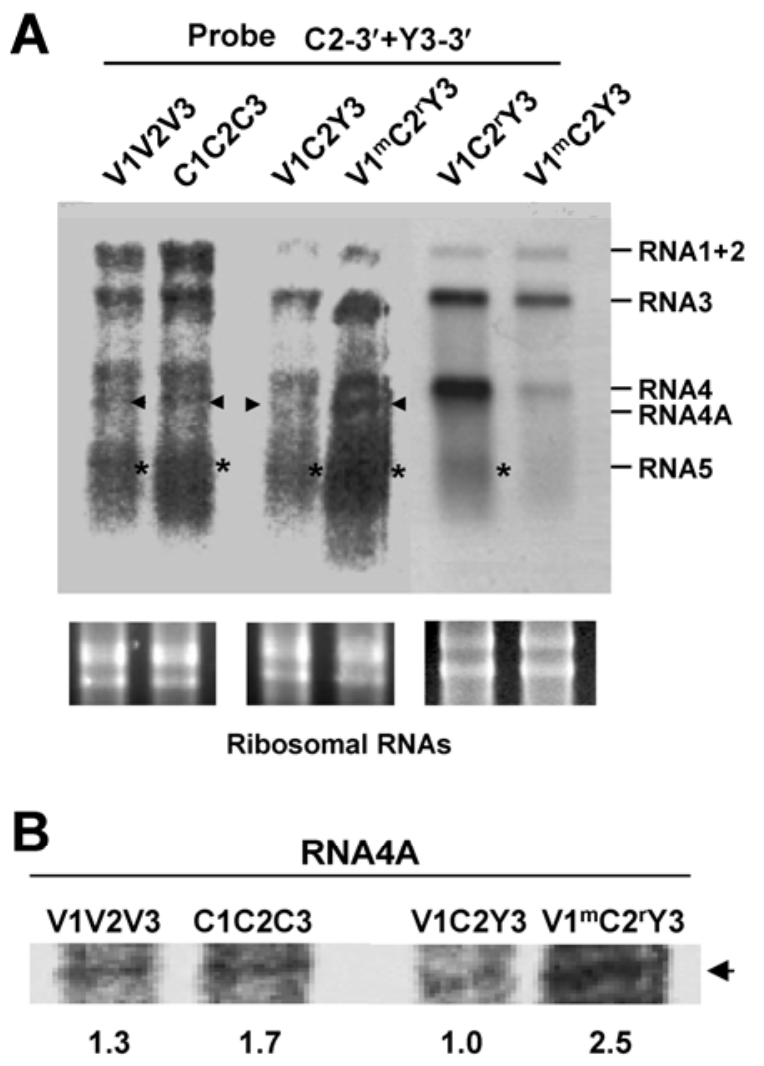

Fig. 3. Northern blot analysis of viral RNAs isolated from tobacco leaves after inoculation with parental Tomato aspermy virus (TAV) and the mutant/recombinant pseudorecombinants. A, Total RNA was extracted from the inoculated leaves 5 days after inoculation. EtBr-stained ribosomal RNAs are indicated as a loading control. The positions of viral RNAs are indicated to the right. Arrowheads and asterisks indicate RNA4A and RNA5, respectively. Probe C2-3' is derived from the 3'-terminal 300-nucleotide (nt) fragment of C-TAV RNA 2 and can detect RNAs 1, 2, 4A, and 5 of C-TAV and V-TAV. Probe Y3-3' is derived from the $3^{\prime}$-terminal $300 \mathrm{nt}$ fragment of Cucumber mosaic virus Y (CMV-Y) RNA 3 and can detect RNA3 and RNA4 of CMV-Y. V1 = RNA1 of V-TAV, V1 ${ }^{\mathrm{m}}=$ containing a mutation at position $1,767, \mathrm{C} 2=\mathrm{RNA} 2$ of $\mathrm{C}-\mathrm{TAV}, \mathrm{C} 2^{\mathrm{r}}=$ a recombinant $\mathrm{C} 2$ containing the $3^{\prime}$ end of V1, Y3 = RNA3 of CMV-Y. B, Close-up of the bands of RNA4A. The values below the image are relative band intensity that was calculated by the Image J software. The intensity of RNA4A band of V1C2Y3 was set at 1.0. An arrowhead indicates RNA4A. 
We then analyzed the viral RNAs isolated from protoplasts and from the viral particle. Northern blot analysis revealed that protoplasts infected with $\mathrm{V} 1{ }^{\mathrm{m}} \mathrm{C} 2^{\mathrm{r}} \mathrm{Y} 3$ contained large amounts of RNA4A and RNA5 compared with those infected with V1C2Y3 (Fig. 4A). Similarly, purified virion of $\mathrm{V} 1^{\mathrm{m}} \mathrm{C} 2^{\mathrm{r}} \mathrm{Y} 3$ contained abundant RNA4A and RNA5 as well as its genomic RNAs 1 to 3 (Fig. 4B). Because RNA4A is the transcript for the $2 b$ protein $(2 b)$, we used an in vitro translation assay to confirm that the integrated RNA4A was translatable (Fig. 4C), suggesting that the virions isolated from the upper leaves contained functional mRNA for $2 b$.

\section{Accumulation of $2 \mathrm{~b}$ is associated with systemic infection of tobacco by $\mathrm{V1}^{\mathrm{m}} \mathrm{C2}{ }^{\mathrm{r}} \mathrm{Y} 3$.}

To investigate whether the levels of RNA4A reflect the levels of $2 b$, we analyzed $2 b$ accumulation in inoculated leaves. Western blot analysis showed that the level of $2 b$ accumulation was higher in the $\mathrm{C} 1 \mathrm{C} 2 \mathrm{C} 3$-infected tobacco leaves than in the V1V2V3-infected leaves (Fig. 5A). On the other hand, the levels of $2 \mathrm{~b}$ accumulation in $N$. benthamiana leaves were almost the same between $\mathrm{C} 1 \mathrm{C} 2 \mathrm{C} 3$ and V1V2V3 (Fig. 5B). In addition, there was a clear difference in the levels of $2 b$ accumulation between $\mathrm{V} 1 \mathrm{C} 2 \mathrm{Y} 3$ and $\mathrm{V} 1{ }^{\mathrm{m}} \mathrm{C} 2^{\mathrm{r}} \mathrm{Y} 3$ in tobacco leaves; $2 \mathrm{~b}$ abundantly accumulated in the $\mathrm{V} 1^{\mathrm{m}} \mathrm{C} 2^{\mathrm{r}} \mathrm{Y} 3$-inoculated tobacco but poorly accumulated in the $\mathrm{V} 1 \mathrm{C} 2 \mathrm{Y} 3$-inoculated tobacco leaves. On the other hand, both $\mathrm{V} 1{ }^{\mathrm{m}} \mathrm{C} 2{ }^{\mathrm{r}} \mathrm{Y} 3$ and $\mathrm{V} 1 \mathrm{C} 2 \mathrm{Y} 3$ caused high levels of $2 b$ accumulation in the inoculated leaves of $N$. benthamiana. These results suggest that the accumulation of $2 b$ is involved in promoting systemic infection of $\mathrm{V} 1{ }^{\mathrm{m}} \mathrm{C} 2{ }^{\mathrm{r}} \mathrm{Y} 3$ in tobacco. To test this possibility directly, we created the Potato virus $X$ (PVX) vector expressing $2 \mathrm{~b}$ of either C-TAV (C2b) or V-TAV (J) (V2b), PVX-C2b and PVX-V2b, respectively. When either $\mathrm{C} 2 \mathrm{~b}$ or $\mathrm{V} 2 \mathrm{~b}$ was overexpressed in trans by the PVX vector, coinoculation with $\mathrm{PVX}-\mathrm{C} 2 \mathrm{~b}$ or
A N. tabacum inoculated leaves

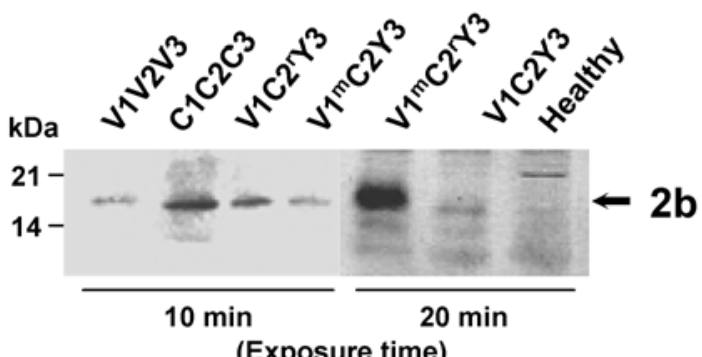

(Exposure time)

B N. benthamiana inoculated leaves

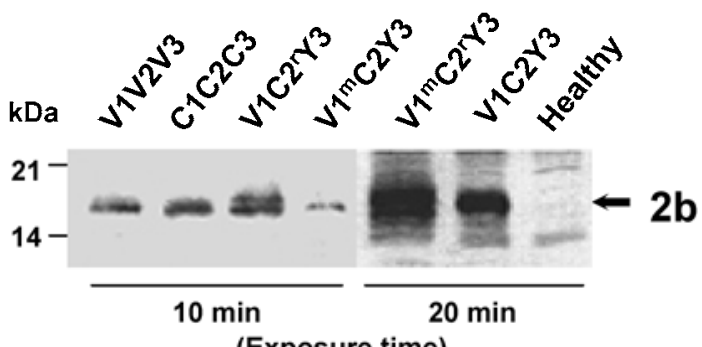

(Exposure time)

Fig. 5. Western blot analysis of the $2 \mathrm{~b}$ protein in the leaves of A, Nicotiana tabacum and $\mathbf{B}, N$. benthamiana inoculated with parental Tomato aspermy virus $(\mathrm{TAV})$ and the mutant/recombinant pseudorecombinants. $\mathrm{V} 1=$ RNA1 of $V$-TAV, $V 1^{\mathrm{m}}=$ containing a mutation at position $1,767, \mathrm{C} 2=$ RNA2 of $\mathrm{C}-\mathrm{TAV}, \mathrm{C} 2^{\mathrm{r}}=$ a recombinant $\mathrm{C} 2$ containing the $3^{\prime}$ end of $\mathrm{V} 1, \mathrm{Y} 3=$ RNA3 of Cucumber mosaic virus Y CMV-Y. A and $\mathbf{B}$, The last three lanes were exposed for $20 \mathrm{~min}$ to ensure there was no nonspecific band at the $2 \mathrm{~b}$ position in the lane "Healthy." The other lanes were exposed for $10 \mathrm{~min}$.

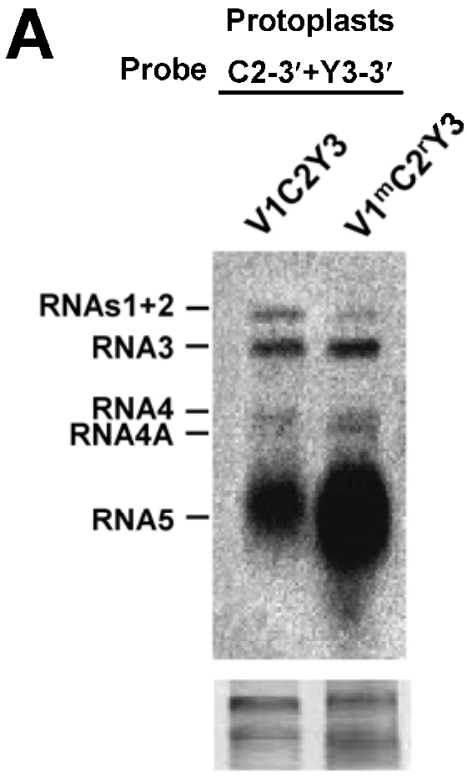

Ribosomal RNAs
B
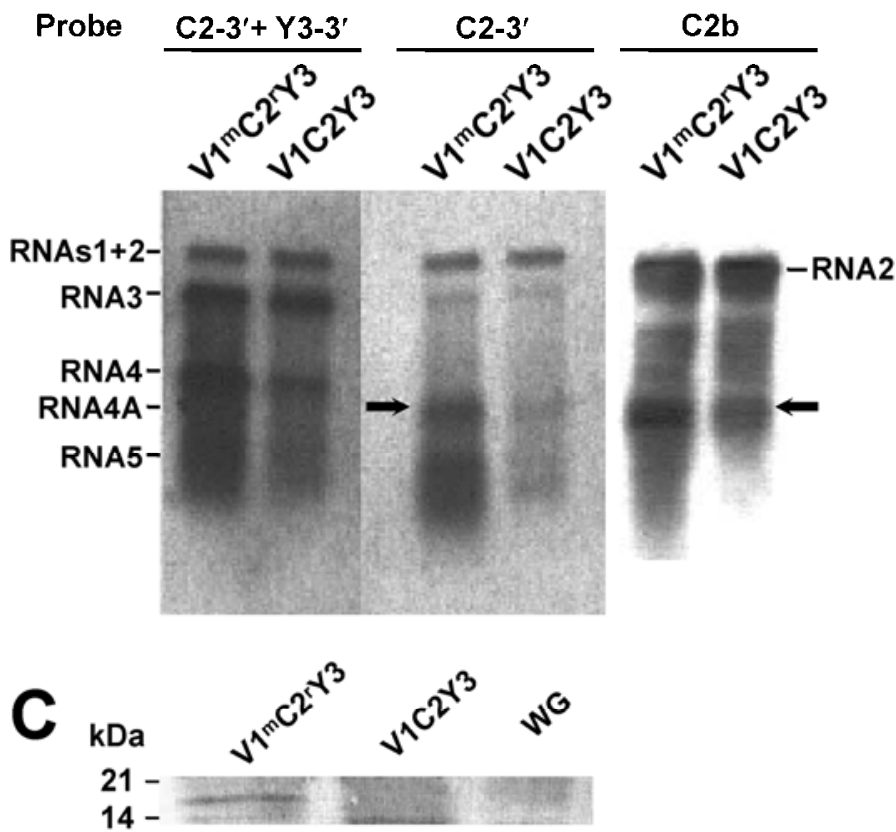

Fig. 4. Northern blot analysis of the viral RNAs isolated from tobacco protoplasts and the encapsidated RNAs in the virion. A, Total RNA was extracted from protoplasts $24 \mathrm{~h}$ after incubation. The decrease in RNAs 1 and 2 of the mutant/recombinant virus may be explained as the consequence of interference with viral replication by abundant RNA5 just like defective interfering RNA or satellite RNA. B, Viral RNAs were prepared from the purified particles. V1 = RNA1 of Tomato aspermy virus $\mathrm{V}(\mathrm{TAV}-\mathrm{V}), \mathrm{V}^{\mathrm{m}}=$ containing a mutation at position $1,767, \mathrm{C} 2=\mathrm{RNA} 2$ of $\mathrm{C}-\mathrm{TAV}, \mathrm{C} 2^{\mathrm{r}}=$ a recombinant $\mathrm{C} 2$ containing the $3^{\prime}$ end of $\mathrm{V} 1, \mathrm{Y} 3=$ RNA3 of Cucumber mosaic virus Y (CMV-Y). Probe C2-3' is derived from the $3^{\prime}$ terminal $300 \mathrm{nt}$ fragment of CMV-Y RNA3 and can detect RNA3 and RNA4 of CMV-Y. Probe $\mathrm{C} 2 \mathrm{~b}$ is the entire $2 \mathrm{~b}$ gene of C-TAV. Arrowheads in B indicate RNA4A. C, Western blot analysis of the in-vitro-translated $2 b$ protein from the encapsidated RNA4A. Viral RNAs in the virion were in vitro translated by the wheat germ (WG) system and the $2 \mathrm{~b}$ protein was detected by anti-2b antibodies. 
PVX-V2b and V1C2Y3 actually resulted in systemic infection. The representative results from the tissue printing are shown in Figure 6. C2b seemed to be a little more effective on the systemic infection than V2b based on the accumulation level in upper leaves. Viral movement was also confirmed by enzymelinked immunosorbent assay (ELISA) (Supplementary Fig. S2).

\section{Accumulation of $2 \mathrm{~b}$ promotes systemic movement in tobacco through its RSS activity.}

One question is raised: why can the $2 b$ accumulation level affect the systemic movement of TAV? Because $2 b$ acts as an RSS (Brigneti et al. 1998) and also plays a role in cucumovirus systemic movement (Ding et al. 1995; Ji and Ding 2001; Soards et al. 2002; Shi et al. 2003; Lewsey et al. 2009), we investigated whether there is any link between the RSS activity of $2 b$ and the systemic movement of TAV in tobacco. When tobacco plants were inoculated with V-TAV (J) (i.e., V1V2V3) and kept at $24^{\circ} \mathrm{C}$, no plants were systemically infected. However, at $15^{\circ} \mathrm{C}, 40 \%$ of the inoculated plants showed systemic symptoms (Fig. 7). Furthermore, when we used a transgenic tobacco expressing 2b of CMV-Y, $10 \%$ of the V1V2V3-inoculated transgenic tobacco was systemically infected at $24^{\circ} \mathrm{C}$ and all the inoculated plants developed systemic symptoms at $15^{\circ} \mathrm{C}$ (Fig. 7). We confirmed that the virus isolated from the upper noninoculated leaves did not contain mutation or recombination by direct sequencing of viral cDNAs. These results suggest that RNA silencing protected against systemic movement of V-TAV $(\mathrm{J})$ in tobacco in the greenhouse $\left(24^{\circ} \mathrm{C}\right)$, considering that low temperature inhibits host RNA silencing (Szittya et al. 2003). Based on the results described, we thought that the RSS activity in $\mathrm{C} 2 \mathrm{~b}$ and $\mathrm{V} 2 \mathrm{~b}$ may differ because the amino acid sequence in the two $2 \mathrm{~b}$ proteins are so different; nine amino acids are deleted in V2b compared with C2b (Supplementary Fig. S3), and overexpression of $\mathrm{C} 2 \mathrm{~b}$ by the PVX vector seemed to be more effective than V2b (Fig. 6). By the Agrobacterium tumefaciens-mediated transient expression assay, which researchers often use to identify and characterize viral $\mathrm{RSS}$, it is difficult to discriminate such small differences in RSS activities; C2b and V2b actually resulted in a similar level of green fluorescent protein fluorescence in both $N$. benthamiana and $N$. tabacum in an agroinfiltration assay (data not shown). To measure RSS activity more strictly, we adapted a protoplast assay that we had developed to quantitate RSS activities (Shimura et al. 2008). The RSS activity in C2b and $\mathrm{V} 2 \mathrm{~b}$ differed very little in $N$. benthamiana protoplasts but $\mathrm{C} 2 \mathrm{~b}$ had somewhat higher RSS activity (approximately 20\% more) than did V2b in tobacco protoplasts (Fig. 8). We obtained similar results in three independent experiments. These results suggest that the increased $2 \mathrm{~b}$ accumulation can promote the systemic movement in tobacco through its RSS activity, and C2b is somewhat better than $\mathrm{V} 2 \mathrm{~b}$ at promoting systemic movement.

\section{DISCUSSION}

In this study, we showed that accumulation of the TAV $2 b$ protein was important for systemic movement in tobacco. Although several other reports also indicate that the cucumovirus $2 \mathrm{~b}$ protein functions in systemic virus movement, our results further demonstrate that the accumulation of $2 b$ to certain high levels is, indeed, essential for TAV systemic movement but that viral systemic movement is not simply determined by the presence or absence of $2 \mathrm{~b}$. We reached this conclusion by analyzing a spontaneous pseudorecombinant virus that had generated mutation and recombination in its genomic RNAs 1 and 2. Pre-
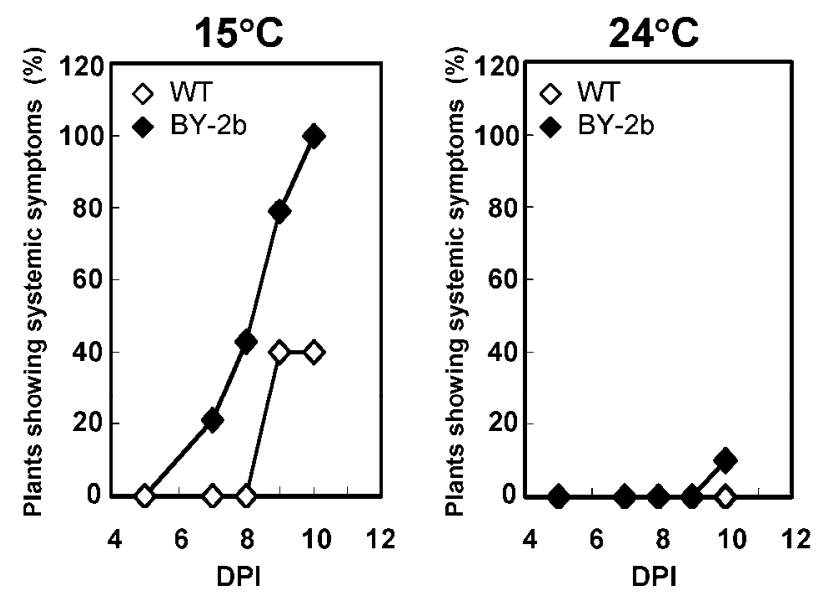

Fig. 7. Effects of low temperature and transgene expression of Cucumber mosaic virus (CMV) 2b on Tomato aspermy virus (TAV) systemic movement in tobacco. BY-2b is the transgenic tobacco plant (Nicotiana tabacum cv. BY4) expressing the $2 b$ protein of CMV-Y. Seven plants in each treatment were inoculated with V-TAV (J) (i.e., V1V2V3). WT = wild type of $N$. tabacum cv. BY4. DPI = days postinoculation. In all cases, the progeny viruses isolated from the upper leaves were amplified by reverse-transcription polymerase chain reaction and sequenced to confirm that those viruses were not mutants or recombinants.

\section{Controls}

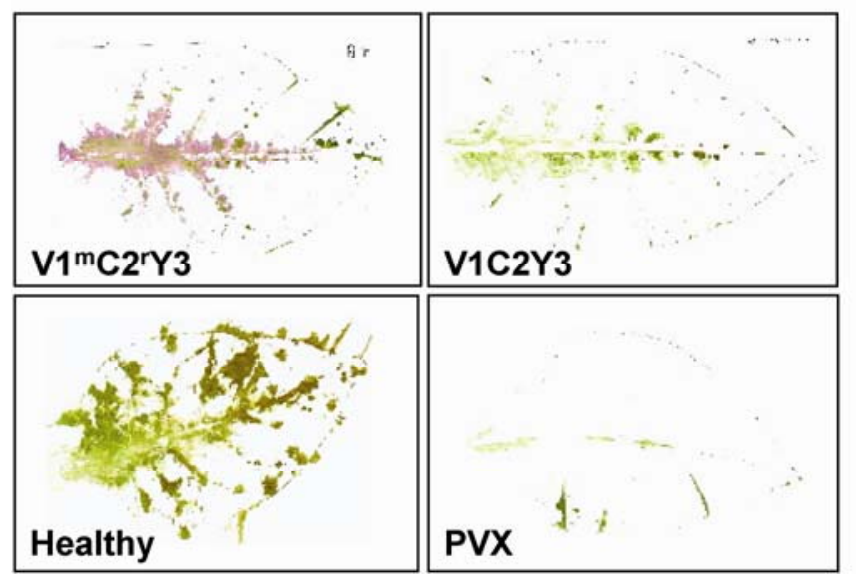

\section{V1C2Y3 + PVX constructs}

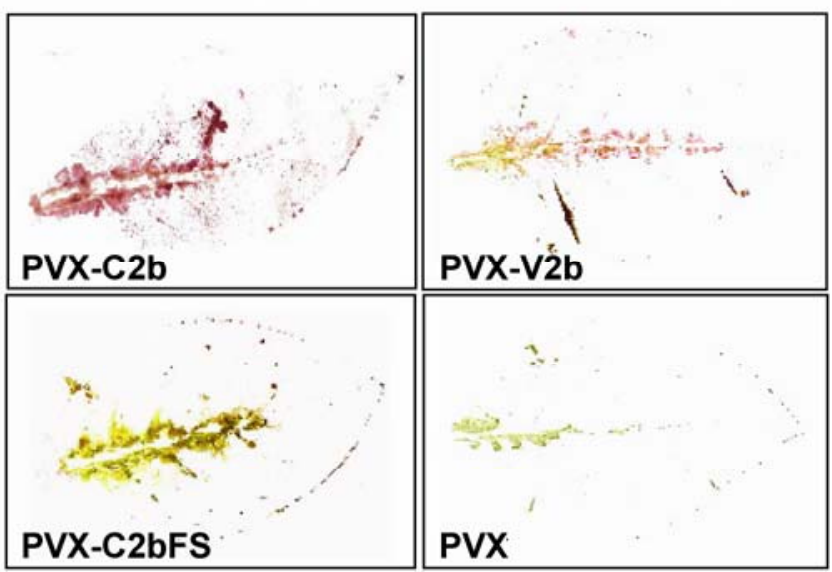

Fig. 6. Tissue print analysis of the upper leaves of Nicotiana tabacum inoculated with V1C2Y3 together with the Potato virus X ( PVX) vector expressing the Tomato aspermy virus (TAV) $2 \mathrm{~b}$ protein. Red areas in photographs indicate the presence of the virus. C2b and V2b are C-TAV $2 \mathrm{~b}$ and $\mathrm{V}-\mathrm{TAV} 2 \mathrm{~b}$, respectively. $\mathrm{C} 2 \mathrm{bFS}$ represents a frame shift construct of $\mathrm{C} 2 \mathrm{~b}$. 
vious observations have shown that pseudorecombinant and chimeric cucumoviruses are not optimized for their interactions either between the viral proteins or with the host factors and, thus, they cannot compete effectively with the parental viruses (Salánki et al. 1997; Shi et al. 2003). However, a spontaneous mutant virus, as studied here, quickly evolved to be a dominant species over the authentic parental RNAs in the RNA populations, implying that there must be some mechanism for generating and, more importantly, for selecting such recombinant/ mutant RNAs. It should be noted that $\mathrm{V} 1^{\mathrm{m}} \mathrm{C} 2^{\mathrm{r}} \mathrm{V} 3$ was initially generated in $N$. benthamiana under relatively weak selection pressure because the parental virus (V1C2V3) could replicate sufficiently and infect systemically in $N$. benthamiana, implying that the mutant/recombinant RNAs simply enhanced the intrinsic ability to move systemically in both $N$. benthamiana and tobacco.

Therefore, we began to study the mechanism by characterizing the mutant/recombinant virus. We found that the purified particle of $\mathrm{V} 1{ }^{\mathrm{m}} \mathrm{C} 2^{\mathrm{r}} \mathrm{Y} 3$ contained huge amounts of RNA4A and RNA5. This observation indicates that the virus can transcribe or stabilize its genomic and subgenomic RNAs more effectively than the parental virus is able to do, by gaining the ability to accumulate a large amount of $2 \mathrm{~b}$ through an increased level of RNA4A. Western blot analyses showed that $\mathrm{V} 1^{\mathrm{m}} \mathrm{C} 2^{\mathrm{r}} \mathrm{Y} 3$ actually accumulated abundant $2 \mathrm{~b}$ compared with levels for V1C2Y3 in both $N$. benthamiana and tobacco leaves. To prove that $2 \mathrm{~b}$ accumulation can promote systemic movement of V1C2Y3, we overexpressed either C-TAV 2b (C2b) or V-TAV $2 \mathrm{~b}(\mathrm{~V} 2 \mathrm{~b})$ in trans using the PVX vector. As expected, overexpression of $2 b$ resulted in systemic infection of V1C2Y3. Therefore, it is conceivable that $\mathrm{V} 1{ }^{\mathrm{m}} \mathrm{C} 2^{\mathrm{r}} \mathrm{Y} 3$ could become a dominant species through an increased ability to accumulate $2 b$.

In addition, systemic appearance of the virus was seen as stronger signals for viral accumulation in the PVX-C2binfected tobacco than in PVX-V2b-infected tobacco. These observations imply that V2b must accumulate somewhat more to effect efficient systemic infection compared with $\mathrm{C} 2 \mathrm{~b}$. Because $2 b$ is known as an RSS, we assessed whether there is any link between systemic movement and the RSS activity of $2 b$. In the inoculation experiments using the $2 \mathrm{~b}$-transgenic tobacco plants, low-temperature treatment and suppression of RNA silencing by $2 \mathrm{~b}$ supplied from the transgene actually facilitated systemic movement of V-TAV, suggesting that RNA silencing in tobacco limits the virus in the inoculated leaves. We further carried out a protoplast assay to compare the RSS activities of $\mathrm{C} 2 \mathrm{~b}$ and $\mathrm{V} 2 \mathrm{~b}$. In three separate experiments, we observed that, in tobacco, $\mathrm{C} 2 \mathrm{~b}$ could suppress Luc silencing approximately $20 \%$ better than V2b but there was little difference in $N$. benthamiana protoplasts. The $2 \mathrm{~b}$ protein of TAV functioned differently in different host plants, indicating that such differences may affect viral propagation and subsequent systemic infection. We previously showed that, even by a small difference in $2 b$ RSS activity in the protoplast system, it was significant enough to affect symptom development (Shimura et al. 2008). This small difference in RSS activity may not be significant enough to suppress host silencing but may contribute to viral movement, especially when the $2 \mathrm{~b}$ level is near the threshold level necessary for viral systemic movement. Although the RSS activity of $2 b$ does not work well, the virus may be able to go over the threshold by enhancing $2 b$ accumulation to certain high levels. Thus, we envisage that whether TAV can infect tobacco systemically is determined by differences in RSS accumulation and activity.

In addition, abundant accumulation of RNA5 in $\mathrm{V} 1{ }^{\mathrm{m}} \mathrm{C} 2^{\mathrm{r}} \mathrm{Y} 3$ appears to be involved in successful systemic movement of $\mathrm{V} 1^{\mathrm{m}} \mathrm{C} 2^{\mathrm{r}} \mathrm{Y} 3$ and the occurrence of RNA recombination. RNA5 has been suggested to be involved in recombination as well as in virus assembly, replication, or both (Blanchard et al. 1996; de Wispelaere et al. 2005; de Wispelaere and Rao 2009). We actually obtained many recombinant clones derived from V1C2V3 progeny and observed that these recombinations occurred frequently at a precise position between RNA1 and RNA2. The recombination seems to occur by a previously postulated mechanism for RNA recombination in cucumoviruses involving the 3 '-terminal UTR and, perhaps, its derivative RNA5 (Suzuki et al. 2003; de Wispelaere et al. 2005; Shi et al. 2008). Indeed, a recent study demonstrated that the cucumovirus $2 \mathrm{~b}$ protein drove selection of interviral recombination through its RSS-related functions and that RNA3 was involved in RNA recombination and its selection (Shi et al. 2008). Therefore, we consider that V-TAV (J) RNA3 has the ability to stimulate mutation and recombination in our inoculation experiments and that both RSS-related activity of 2b and RNA5related mechanisms play a role in the generation and selection of such mutant/recombinant viruses. Furthermore, the mutant/ recombinant viruses accumulated a lot more viral RNAs, including RNA4A, leading to the $2 \mathrm{~b}$ accumulation. Because the viral RNAs share the same 3'-terminal sequences, a high level of RNA5 in $\mathrm{V} 1{ }^{\mathrm{m}} \mathrm{C} 2^{\mathrm{r}} \mathrm{Y} 3$ must interfere with the degradation of its genomic and subgenomic RNAs in the host RNA-silencing machinery and, thus, $\mathrm{V} 1^{\mathrm{m}} \mathrm{C} 2^{\mathrm{r}} \mathrm{Y} 3$ could eventually accumulate abundant $2 \mathrm{~b}$ and move systemically. Therefore, we believe that there is a synergistic linkage between the generation of recombination and the accumulation of RNA4A and RNA5, leading to the $2 \mathrm{~b}$ accumulation and subsequent viral systemic movement (Supplementary Fig. S4).

It still is not clear how $2 \mathrm{~b}$ influences systemic movement through its RSS-related activity at the molecular level; however, elevated levels of $2 b$ accumulation certainly promote systemic movement of the virus, which is essential for the virus to survive in nature. It is also noteworthy that, due to such a high level of $2 b$, the mutant/recombinant RNAs could quickly evolve to become the dominant species, outcompeting the parental RNAs. Therefore, we suggest that $2 \mathrm{~b}$ may also play a major role in Cucumovirus evolution through its RSS activity.
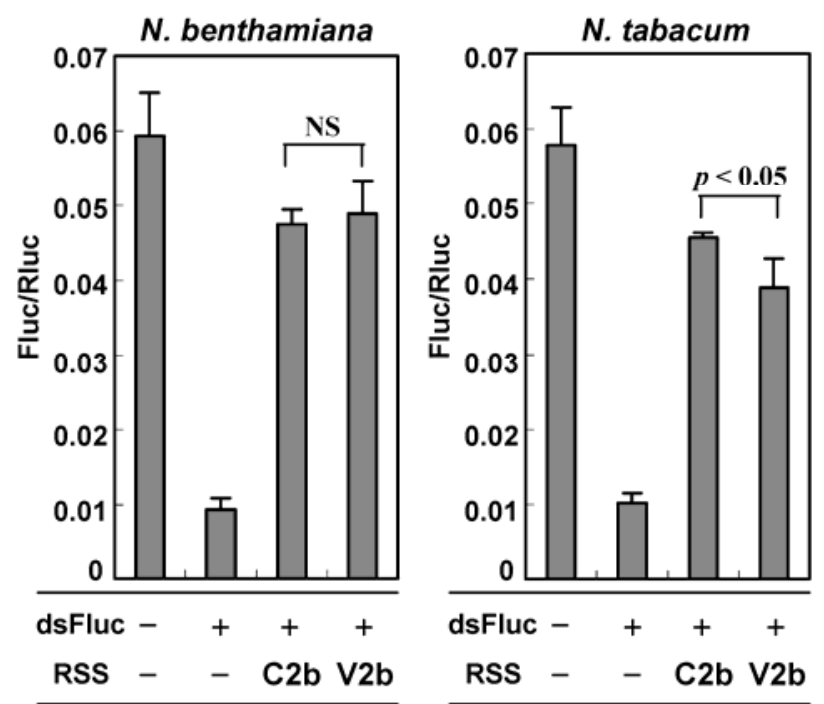

Fig. 8. Comparison of RNA-silencing suppressor (RSS) activities of Tomato aspermy virus (TAV) $2 \mathrm{bs}$ in protoplasts of Nicotiana benthamiana and N. tabacum. The relative firefly luciferase (Fluc) activity was calculated by dividing the measured value of Fluc by that of Renilla luciferase (Rluc). Results are given as means with standard deviations (SD) obtained from three replicates. Statistical significance of difference in RSS activities between $\mathrm{C} 2 \mathrm{~b}$ and V2b was calculated with Student's $t$ test (NS, not significant). $\mathrm{C} 2 \mathrm{~b}=\mathrm{C}-\mathrm{TAV} 2 \mathrm{~b}$ and V2b $=$ V-TAV $2 \mathrm{~b}$; dsFluc $=$ doublestranded RNA of the Fluc gene. 


\section{MATERIALS AND METHODS}

\section{Virus and plant materials.}

An uncloned isolate of V-TAV was supplied by F. GarcíaArenal (Department de Biotecnología, ETSI Agrónomos, Madrid, Spain) and propagated in N. benthamiana. Compared with the original TAV, this derivative isolate had nucleotide changes in RNAs 1 and 2 and was designated as V-TAV (J) (Masuta et al. 1998). C-TAV was originally isolated from chrysanthemum and maintained in our laboratory (Takahashi et al. 2005). Plasmids containing full-length cDNA clones of CMV$\mathrm{Y}$ and V-TAV $(\mathrm{J})$ were previously constructed (Suzuki et al. 1991; Masuta et al. 1998). The infectious cDNA clones of CTAV were similarly prepared. $N$. benthamiana and $N$. tabacum cv. BY4 were used in the inoculation experiments and maintained in the greenhouse at $24^{\circ} \mathrm{C}$ in natural light. For the $15^{\circ} \mathrm{C}$ incubation, an MLR-350 growth chamber (SANYO, Tokyo) was used with a $16-\mathrm{h}$ photoperiod $\left(150 \mu \mathrm{mol} / \mathrm{m}^{2} / \mathrm{s}\right)$. A transgenic tobacco line expressing the $2 \mathrm{~b}$ protein was generated by transforming $N$. tabacum cv. BY4 with a binary vector pBE2113 (Mitsuhara et al. 1996) carrying the $2 b$ gene of CMV-Y under the Cauliflower mosaic virus $35 \mathrm{~S}$ promoter.

\section{Inoculation of plants and protoplasts.}

Biologically active RNAs were transcribed from full-length cDNA clones. In vitro transcription was carried out essentially as described by Suzuki and associates (1991). Pseudorecombinant viruses were created by mixing in vitro-synthesized transcripts. To obtain an initial inoculum, we first mechanically inoculated $N$. benthamiana leaves with pooled transcripts using Carborundum. The inoculum for further experiments was then prepared by grinding infected tissues in $0.1 \mathrm{M}$ phosphate buffer ( $\mathrm{pH}$ 7.0). Protoplasts were inoculated with the virus as described by Yamaguchi and associates (2005). Viral accumulation was measured using a conventional ELISA.

\section{Northern blot analysis.}

Total RNA was extracted by either a conventional phenol/ chloroform method according to Senda and associates (2004) or the method using Trizol reagent (Invitrogen, Carlsbad, CA, U.S.A.) following the manufacturer's instructions. Northern hybridization was performed essentially as described by Goto and associates (2007). Probes were generated by PCR with a PCR digoxigenin (DIG) Probe Synthesis Kit (Roche Diagnostics, Tokyo) using the primers to amplify the 3 '-terminal regions of C-TAV RNA 2 (probe C2-3') and CMV-Y RNA 3 (probe Y3-3'). Probe C2-3' can detect RNAs 1, 2, 4A, and 5 of TAV. Probe Y3-3' can detect RNAs 3 and 4 of CMV. The DIGlabeled $2 \mathrm{~b}$ gene of C-TAV (probe $\mathrm{C} 2 \mathrm{~b}$ ) was also used as a probe to detect RNA4A. For some experiments, the intensity of the band detected by Northern blots was determined by Image J software (Abramoff et al. 2004).

\section{Western blot analysis, tissue printing, and press blotting.}

At 7 to $10 \mathrm{dpi}$, the inoculated leaves were harvested and protein extraction and western blot analysis were performed as described by Masuta and associates (1995). Protein levels were estimated using the DC protein assay (Bio-Rad, Hercules, CA, U.S.A.). The total proteins $(50 \mu \mathrm{g})$ were separated on sodium dodecyl sulfate polyacrylamide gel electrophoresis in $12.5 \%$ gels. The $2 \mathrm{~b}$ protein was probed with rabbit polyclonal antibodies raised against the V-TAV 2 b produced by Escherichia coli. RNA4A encapsidated in the particle was in vitro translated with the wheat germ extract system (PROTEIOS) (TOYOBO, Osaka, Japan) at $26^{\circ} \mathrm{C}$ for $20 \mathrm{~h}$ according to the manufacturer's instructions. The translation products were then subjected to Western blot analysis to detect the $2 \mathrm{~b}$ protein. Tissue prints and press blots on nitrocellulose membrane were prepared essentially as described by Masuta and associates (1999). The viral accumulations were detected $14 \mathrm{dpi}$ in the upper leaves of the plants using the antibodies raised against the CP of CMV-Y.

\section{PVX vector construct.}

The PVX vector was obtained from D. C. Baulcombe (The Sainsbury Laboratory, Norwich, U.K.) and the $2 \mathrm{~b}$ genes of VTAV (V2b) and C-TAV (C2b) were cloned into the PVX vector. $N$. benthamiana leaves were inoculated with in vitro transcripts of the recombinant constructs to make inocula for further inoculation experiments.

\section{Protoplast assay for RNA silencing suppressors.}

Protoplasts were prepared from leaves of either $N$. benthamiana or N. tabacum cv. BY-4 as described by Shimura and associates (2008). We used the luciferase gene as a reporter gene; firefly luciferase (Fluc) was the target of RNA silencing and Renilla luciferase (Rluc) was the internal control for transfection (Shimura et al. 2008). The 2b genes of V-TAV (V2b) and C-TAV (C2b) were cloned in pE2113 (Mitsuhara et al. 1996). As a silencing inducer, double-stranded RNA of the Fluc gene (dsFluc) was prepared by in vitro transcription using a PCR-amplified fragment containing the $\mathrm{T} 7$ promoter sequence at both the $5^{\prime}$ and $3^{\prime}$ ends. RNA silencing in protoplasts was induced by co-transfecting with the reporter genes and dsFluc with or without the plasmids containing the suppressor genes. Transfection of protoplasts was performed according to the protocol in Shimura and associates (2008). Transfected protoplasts were incubated for $24 \mathrm{~h}$ in the dark at $25^{\circ} \mathrm{C}$. After incubation, protoplasts were harvested and analyzed for luciferase activity using the Dual-Luciferase Reporter Assay System (Promega Corp., Madison, WI, U.S.A.).

\section{ACKNOWLEDGMENTS}

We thank F. García-Arenal and D. C. Baulcombe for providing us with V-TAV and the PVX vector, respectively, and N. Myojo for his technical assistance.

\section{LITERATURE CITED}

Aaziz, R., and Tepfer, M. 1999. Recombination between genomic RNAs of two cucumoviruses under conditions of minimal selection pressure. Virology 263:282-289.

Abramoff, M. D., Magelhaes, P. J., and Ram, S. J. 2004. Image processing with ImageJ. Biophotonics Int. 11:36-42.

Blanchard, C. L., Boyce, P. M., and Anderson, B. J. 1996. Cucumber mosaic virus RNA5 is a mixed population derived from the conserved 3'terminal regions of genomic RNAs 2 and 3. Virology 217:598-601.

Bonnet, J., Fraile, A., Sacristán, S., Malpica, J. M., and García-Arenal, F. 2005. Role of recombination in the evolution of natural populations $\mathrm{Cu}$ cumber mosaic virus, a tripartite RNA plant virus. Virology 332:359-368.

Brigneti, G., Voinnet, O., Li, W. X., Ji, L.-H., Ding, S.-W., and Baulcombe, D. C. 1998. Viral pathogenicity determinants are suppressors of transgene silencing in Nicotiana benthamiana. EMBO (Eur. Mol. Biol. Organ.) J. 17:6739-6746.

Canto, T., Choi, S. K., and Palukaitis, P. 2001. A subpopulation of RNA 1 of Cucumber mosaic virus contains $3^{\prime}$ termini originating from RNAs 2 or 3. J. Gen. Virol. 82:941-945.

Chen, Y. K., Goldbach, R., and Prins, M. 2002. Inter- and intramolecular recombinations in the Cucumber mosaic virus genome related to adaptation to alstroemeria. J. Virol. 76:4119-4124.

Ding, S.-W., Li, W. X., and Symons, R. H. 1995. A novel naturally occurring hybrid gene encoded by a plant RNA virus facilitates long distance virus movement. EMBO (Eur. Mol. Biol. Organ.) J. 14:5762-5772.

de Wispelaere, M., and Rao, A. L. N. 2009. Production of Cucumber mosaic virus RNA5 and its role in recombination. Virology 341:179-191.

de Wispelaere, M., Gaubert, S., Trouilloud, S., Belin, C., and Tepfer, M. 2005. A map of the diversity of RNA3 recombinants appearing in plants infected with Cucumber mosaic virus and Tomato aspermy virus. Virology 331:117-127. 
Fernández-Cuartero, B., Burgyán, J., Aranda, M. A., Salánki, K., Moriones, E., and García-Arenal. F. 1994. Increase in the relative fitness of a plant virus RNA associated with its recombinant nature. Virology 203:373-377.

Goto, K., Kobori, T., Kosaka, Y., Natsuaki, T., and Masuta, C. 2007. Characterization of silencing suppressor $2 \mathrm{~b}$ of Cucumber mosaic virus based on examination of its small RNA-binding abilities. Plant Cell Physiol. 48:1050-1060.

Ji, L.-H., and Ding, S.-W. 2001. The suppressor of transgene RNA silencing encoded by Cucumber mosaic virus interferes with salicylic acidmediated virus resistance. Mol. Plant-Microbe Interact. 14:715-724.

Lewsey, M., Surette, M., Robertson, F. C., Ziebell, H., Choi, S. H., Ryu, K. H., Canto, T., Palikaitis, P., Payne, T., Walsh, J. A., and Carr, J. P. 2009. The role of the Cucumber mosaic virus $2 \mathrm{~b}$ protein in viral movement and systemic induction. Mol. Plant-Microbe Interact. 22:642-654.

Lin, H. X., Rubio, L., Smythe, A. B., and Falk, B. W. 2004. Molecular population genetics of Cucumber mosaic virus in California: evidence for founder effects and reassortment. J. Virol. 78:6666-6675.

Masuta, C., Tanaka, H., Uehara, K., Kuwata, S., Koiwai, A., and Noma, M. 1995. Broad resistance to plant viruses in transgenic plants conferred by antisense inhibition of a host gene essential in $S$-adenosylmethionine-dependent transmethylation reactions. Proc. Natl. Acad. Sci. U.S.A. 92:6117-6121.

Masuta, C., Ueda, S., Suzuki, M., and Uyeda, I. 1998. Evolution of a quadripartite hybrid virus by interspecific exchange and recombination between replicase components of two related tripartite RNA viruses. Proc. Natl. Acad. Sci. U.S.A. 95:10487-10492.

Masuta, C., Nishimura, M., Morishita, H., and Hataya, T. 1999. A single amino acid change in viral genome-associated protein of Potato virus $Y$ correlates with resistance breaking in 'virgin a mutant' tobacco. Phytopathology 89:118-123.

Mitsuhara, I., Ugaki, M., Hirochika, H., Ohshima, M., Murakami, T., Gotoh, Y., Katayose, Y., Nakamura, S., Honkura, R., Nishimiya, S., Ueno, K., Mochizuki, A., Tanimoto, H., Tsugawa, H., Ostuki, Y., and Ohashi, Y. 1996. Efficient promoter cassettes for enhanced expression of foreign genes in dicotyledonous and monocotyledonous plants. Plant Cell Physiol. 37:49-59.

Salánki, K., Carrère, I., Jacquemond, M., Balázs, E., and Tepfer, M. 1997. Biological properties of pseudorecombinant and recombinant strains created with Cucumber mosaic virus and Tomato aspermy virus. J. Virol. 71:3597-3602.

Senda, M., Masuta, C., Ohnishi, S., Goto, K., Kasai, A., Sano, T., Hong, J.-S., and MacFarlane, S. 2004. Patterning of virus-infected Glycine max seed coat is associated with suppression of endogenous silencing of chalcone synthase genes. Plant Cell 16:807-818.
Shi, B.-J., Ding, S.-W., and Symons, R. H. 1997. Two novel subgenomic RNAs derived from RNA3 of tomato aspermy cucumovirus. J. Gen. Virol. 78:505-510.

Shi, B.-J., Miller, J., Symons, R. H., and Palukaitis, P. 2003. The 2b protein of cucumoviruses has a role in promoting the cell-to-cell movement of pseudorecombinant viruses. Mol. Plant-Microbe Interact. 16:261267.

Shi B.-J., Symons, R. H., and Palukaitis, P. 2008. The Cucumovirus 2b gene drives selection of inter-viral recombinants affecting the crossover site, the acceptor RNA and the rate of selection. Nucleic Acids Res. 36:1057-1071.

Shimura, H., Fukagawa, T., Meguro, A., Yamada, H., Oh-hira, M., Sano, S., and Masuta, C. 2008. A strategy for screening an inhibitor of viral silencing suppressors, which attenuates symptom development of plant viruses. FEBS (Fed. Eur. Biochem. Soc.) Lett. 582:4047-4052.

Soards, A. J., Murphy, A. M., Palukaitis, P., and Carr, J. P. 2002. Virulence and differential local and systemic spread of Cucumber mosaic virus in tobacco are affected by the CMV $2 \mathrm{~b}$ protein. Mol. Plant-Microbe Interact. 15:647-653.

Suzuki, M., Kuwata, S., Kataoka, J., Masuta, C., Nitta, N., and Takanami, Y. 1991. Functional analysis of deletion mutants of Cucumber mosaic virus RNA 3 using an in vitro transcription system. Virology 183:106113.

Suzuki, M., Hibi, T., and Masuta, C. 2003. RNA recombination between cucumoviruses: possible role of predicted stem-loop structures and an internal subgenomic promoter-like motif. Virology 306:77-86.

Szittya, G., Silhavy, D., Molnár, A., Havelda, Z., Lovas, A., Lakatos, L., Bánfalvi, Z., and Burgyán J. 2003. Low temperature inhibits RNA silencing-mediated defence by the control of siRNA generation. EMBO (Eur. Mol. Biol. Organ.) J. 22:633-640.

Takahashi, H., Shimizu, A., Arie, T., Rosmalawati, S., Fukushima, S., Kikuchi, M., Hikichi, Y., Kanda, A., Takahashi, A., Kiba, A., Ohnishi, K., Ichinose, Y., Taguchi, F., Yasuda, C., Kodama, M., Egusa, M Masuta, C., Sawada, H., Shibata, D., Hori, K., and Watanabe, Y. 2005. Catalog of Micro-Tom tomato responses to common fungal, bacterial, and viral pathogens. J. Gen. Plant Pathol. 71:8-22.

Yamaguchi, N., Seshimo, Y., Yoshimoto, E., Ahn, H. I., Ryu, K. H., Choi, J. K., and Masuta, C. 2005. Genetic mapping of the compatibility between a lily isolate of Cucumber mosaic virus and a satellite RNA. J. Gen. Virol. 86:2359-2369.

Zhang, X., Yuan, Y.-R., Pei, Y., Lin, S.-S., Tuschl, T., Patel, D. J., and Chua, N.-H. 2006. Cucumber mosaic virus-encoded $2 \mathrm{~b}$ suppressor inhibits Arabidopsis Argonaute1 cleavage activity to counter plant defense. Genes Dev. 20:3255-3268. 